The University of San Francisco

USF Scholarship: a digital repository @ Gleeson Library |

Geschke Center

School of Education Faculty Research

School of Education

2016

\title{
Brown Bodies and Xenophobic Bullying in US Schools: Critical Analysis and Strategies for Action
}

Monisha Bajaj

University of San Francisco, mibajaj@usfca.edu

Ameena Ghaffar-Kucher

Karishma Desai

Follow this and additional works at: http://repository.usfca.edu/soe_fac

Part of the Education Commons, and the Sociology Commons

\section{Recommended Citation}

Monisha Bajaj, Ameena Ghaffar-Kucher, and Karishma Desai (2016) Brown Bodies and Xenophobic Bullying in US Schools: Critical Analysis and Strategies for Action. Harvard Educational Review: Winter 2016, Vol. 86, No. 4, pp. 481-505. https://doi.org/10.17763/ 1943-5045-86.4.481

This Article is brought to you for free and open access by the School of Education at USF Scholarship: a digital repository @ Gleeson Library | Geschke Center. It has been accepted for inclusion in School of Education Faculty Research by an authorized administrator of USF Scholarship: a digital repository@ Gleeson Library| Geschke Center. For more information, please contact repository@usfca.edu. 


\section{PRE-PRINT VERSION}

The following is the author's final draft of an article that, after editing and typesetting, was published as:

"Brown Bodies and Xenophobic Bullying in U.S. Schools: Critical Analysis and Strategies for Action"

By Monisha Bajaj, Ameena Ghaffar-Kucher, \& Karishma Desai

Harvard Educational Review, vol. 86:4 (Winter 2016) pp. 481-505

http://hepg.org/her-home/issues/harvard-educational-review-volume-86-number-

4/herarticle/brown-bodies-and-xenophobic-bullying-in-us-schools

This copy is intended for non-commercial research and educational use, including for instruction at the author's institution and sharing with colleagues, as well as for archiving purposes. All other uses, such as reproduction and distribution, or selling or licensing copies, or posting to third party websites, are prohibited.

For further information, or for permission to reprint or to purchase copies of the final published version of the article, please contact Harvard Education Publishing Group (HEPG) at hepg@ harvard.edu, or 617-495-3432.

The Harvard Educational Review (ISSN 0017-8055) is a scholarly journal of opinion and research in education. Its mission is to provide an interdisciplinary forum for discussion and debate about education's most vital issues. Since its founding in 1930, the Review has become a widely recognized journal in education, with circulation to policymakers, researchers, administrators, and teachers. The Review is published by Harvard Education Publishing Group. Harvard Educational Review

Contact HEPG at:

8 Story Street, 1st Floor

Cambridge, MA 02138

617-495-3432 ph

617-496-3584 fax

hepg@ harvard.edu

http://www.harvardeducationalreview.org

Thank you. 


\title{
Brown Bodies and Xenophobic Bullying in U.S. Schools: Critical Analysis and Strategies for Action
}

\author{
By Monisha Bajaj, Ameena Ghaffar-Kucher, \& Karishma Desai
}

\begin{abstract}
:
This essay addresses an evidence-based action project that sought to interrupt and transform bullying behaviors directed at South Asian American youth in schools in the United States (U.S.). In the context of this essay and project, the authors argue that larger macro-level forces that promote misinformation about youth who inhabit brown bodies (in the U.S. and abroad) have given rise to behaviors identified as bullying, and in some cases, harassment and hate crimes in schools. Conventional literature on bullying offers inadequate frames for how the forces of Islamophobia — that affect all those perceived to be Muslim—and bullying come together to shape realities for youth in schools. This essay advances new frameworks and strategies for understanding xenophobic and bias-based bullying, and explores schools as sites of possibility to interrupt Islamophobia and misinformation about South Asian Americans.
\end{abstract}

Keywords:

Islamophobia, bullying, xenophobia, racism, South Asia, Asian-Americans, critical race theory 


\section{Introduction}

Jajpee, a 17-year-old Sikh American student born and raised in Georgia, has been regularly bullied since the $2^{\text {nd }}$ grade, from name calling and peer accusations that he has a bomb in his turban, to physical violence that left him with a broken nose, a chin fracture and bruises all over. His older sister reported, "He was sitting there with blood all over him and an ice pack in his hand and kids were telling him 'go back to your country. ", That particular beating required two surgeries and when he came back to school, not only did the bullying continue, his sister says the school did nothing at all to address it. (Lee, 2015)

Khoshnoor came to New York from Pakistan in the $8^{\text {th }}$ grade. She was bullied from the moment she got to her school: her hijab was constantly pulled off by peers, she was called "stinky," "ugly" and "terrorist." Students would throw things at her, such as balled up pieces of paper with explicit or lewd comments. Some would even throw basketballs forcefully at her. She reported these incidents to teachers multiple times, but no one did anything to help. She never told her mother because she felt it was pointless. (Paracha, 2008)

With countless stories like Jajpee's and Khoshnoor's in our consciousness as South Asian educators in the U.S., we came together after the horrific 2012 shooting by a self-proclaimed white supremacist at a gurdwara (Sikh temple) in Wisconsin, to discuss how the increasing instances of Islamophobic violence in and beyond schools might be addressed through curricular intervention. As education scholars and professionals-for many years, a classroom teacher (Karishma Desai), an after-school educator and youth development worker (Monisha Bajaj), a school psychologist (Ameena Ghaffar-Kucher), and all of us researchers of educational 
phenomena - we had seen how Islamophobia was on the rise in schools, sometimes propagated by reductive curricula and uninformed teachers (Ghaffar-Kucher, 2012). We also had experience organizing towards allyship and solidarity, as we believe schools to be sites of possibility (Freire, 1970). In our process of creating a curricular intervention based on extant research, policy reports and discussions with experts and advocates, we came across hundreds of stories like the two opening vignettes of xenophobic bullying in schools. The voices and experiences of youth like Jajpee and Khoshnoor are central to this project and serve as the impetus for creating curricular resources that expand the empathic frame of who is 'American,' 'human' and 'worthy' of dignity.

Who does and does not belong to the nation are ideas that are sown into schools. Schools mirror larger forces of exclusion and inequality in society, and this essay focuses on the consequences of the rise of Islamophobia — the fear or dislike of Islam—in the post September 11, 2001 period (“post-9/11"). ${ }^{1}$ Specifically, the post-9/11 climate in the U.S. has seen an increase in violence against Muslims and those perceived to be Muslims, namely, all South Asians and many other groups as well—a notable addition to the way Islamophobia operates to the detriment of many beyond those whom discrimination is intended for. Though not a new phenomenon historically, South Asian Americans (who number 3.4 million in the U.S.) have been targets of hate crimes, harassment and school-based bullying and violence in increasing numbers since 2001 .

\footnotetext{
We are grateful to Samip Mallick, director of SAADA and Deepa Iyer, former director of SAALT for their partnership in creating the resource pack we discuss in this piece. We also thank Lesley Bartlett for her important feedback on drafts of this essay.

${ }^{1}$ Following the Runnymede Trust Commission (2005) in the United Kingdom, we agree that, in fact, there are a multitude of "Islamophobias" rather than a single phenomenon, "each version of Islamophobia has its own features as well as similarities with, and borrowings from, other versions" (p. 2). In this article, we focus on how the forms of Islamophobia directed at those perceived to be Muslim operate in and around schools.
} 
In this essay, we seek to demonstrate how macro-level institutional forces [e.g. the globalization of Islamophobia in political and media discourse (Rana, 2011), and U.S. military engagement in Muslim-majority lands abroad], when coupled with meso-level factors (e.g., poorly developed curricula and inadequate teacher professional development), spawn micro-level expressions of bias among peers and teachers, creating a hostile climate for any youth perceived to be Muslim. Unlike conventional scholarship on bullying, we draw a direct link from the micro to the macro, asserting that larger social and political forces that promote one-sided, singular narratives about wars overseas (e.g., the namelessness of citizens of other nations killed by drones), have given rise to the construction of those people of brown skin as "Other," "terrorist" and "enemy." In U.S. schools, this is manifested through a range of behaviors that we identify as bullying, and in some cases, harassment, abuse and hate crimes.

The literature on bullying mentions in passing bullying based on race or religion, but is often silent about how the forces of xenophobia and racism come together to shape realities for youth in schools. Particularly absent from bullying literature is how misinformation and ignorance — fueled by discourses of national security — can be propagated by teachers, school staff and other families, rendering the bullying of South Asian American youth either invisible or deemed unworthy of action. Utilizing insights from critical race theory by exploring the intersections of racism, xenophobia and bullying offers a clearer picture of where and how this project sought to intervene in addressing the realities of South Asian American youth in U.S. schools. We posit that because schools are, in many ways, a microcosm of society and reflect the prevailing socio-political climate, greater attention is warranted to understand how xenophobia and contemporary racism significantly inflect youth experiences of bullying in schools. 
In what follows, we first describe the impetus for our project rooted in our lived experiences and pedagogical commitments. We then describe how conventional bullying literature overlooks the particularities of xenophobic bullying. Next, we discuss how we utilized key insights from a structural and historical analysis of racism and Islamophobia as it plays out in educational settings to develop an intervention that sought to address the roots of such bullying rather than solely the symptoms. Subsequently, we discuss the curriculum itself, including the strengths and shortcomings of the project, and offer an invitation to educators to join us in conversation about addressing xenophobic bullying through engagement with the curricular resource. Finally, we provide concluding thoughts on the project vis-à-vis larger issues of belonging, citizenship and inclusion in U.S. schools.

Attending to the three levels we introduce in this essay to the literature on bullying, from the macro-level, we trace the circulation of Islamophobic discourses (Rana, 2011) to the microlevel, exemplified through acts of xenophobic bullying in schools. We pay attention to the mesolevel of intermediation by teachers often providing a null or hidden curriculum (Flinders et al., 1986) that supports such xenophobia. We then discuss our action-based curricular project developed to respond to this increase in bullying of South Asian American youth. ${ }^{2}$ This intervention sought to catalyze the potential of the meso-level to serve as a space to rethink epistemological assumptions about South Asians in the U.S., to cultivate empathy and to build solidarity; we also sought to enhance and encourage teacher agency in interrupting Islamophobic discourses in schools and communities. This project can inform others who seek to examine how

\footnotetext{
${ }^{2}$ Despite some accounts that bullying behavior is actually decreasing in schools, our study finds that xenophobic and race-based bullying behavior is actually on the rise. There is a central tension in the data vis-à-vis reports of bullying versus actual bullying that skews our understanding of whether occurrences are actually increasing in frequency, or have remained consistent and more awareness is resulting in greater instances of reporting bullying.
} 
larger structural forms of bias manifest in and around schools through bullying, and can also serve as an example of engaged scholarship where resources and tools from the academy are paired with community needs: in this case, to produce an evidence-based curricular resource packet to interrupt xenophobic bullying.

\section{Our Starting Point}

\section{Defining Terms}

The Islamophobic tenor that prevails at all levels (global, national and local) converges to create a hostile environment for youth with "brown bodies" (Rana, 2011). We understand the risk of a potentially essentialist term such as "brown bodies." 3 However, it encapsulates the perception of foreignness and illegality post-9/11 that has marked many groups — South Asian, West Asian, ${ }^{4}$ North African and various other communities of color [e.g., there was at least one case of a Native American woman who was killed in a post-9/11 hate crime in 2001 (Maira, 2009)]. There is also an increasing discourse of the U.S.-Mexico border as a site for terrorist activity that has since colored debates on immigration (Rivera, 2014). Rivera terms this conflation by the media and government policy of Muslims and Latinx ${ }^{5}$ as dangerous, the "brown threat." Thus, we use the term "brown bodies" as a signifier of how "foreign-ness" is mapped onto particular communities, and reconstructed in classrooms, communities and the media as threatening, and how xenophobic bullying and harassment has psychological and corporeal impacts on the bodies of young people.

\footnotetext{
${ }^{3}$ We have not utilized the term 'brown bodies' in the curricular packet for educators and students because of the complex ways it might be understood.

${ }^{4}$ We prefer the term "West Asia" to "Middle East" given the colonial origins of the latter.

5 The term "Latinx" encompasses men, women and gender non-conforming individuals with Latin American heritage.
} 
While the phenomena we discuss affect many communities, we decided to focus on South Asian Americans for this curricular project given the community partnerships we developed and the gap in resources providing information to and about this community. South Asian Americans - whose families (perhaps many generations ago) originally hail from the countries of Afghanistan, Bangladesh, Bhutan, India, the Maldives, Nepal, Pakistan, and Sri Lanka—have diverse religious backgrounds, including Hindu, Muslim, Sikh, Jain, Christian, Jewish, Buddhist, Baha'i and Zoroastrian (SAALT, 2012). Mainstream U.S. media and larger xenophobic discourses often flatten and elide the diversity among this population and present all members of this group as newcomers with "funny" accents. In fact, South Asian migration to the U.S. is not a new phenomenon at all: it started as early as the 1700 s, but increased drastically after the immigration reforms of 1965 spurred by the Civil Rights movement's attention to unfair restrictions and quotas on migration from non-European countries (Prashad, 2005). From 2000 to 2010, South Asian Americans were the fastest growing major ethnic group according to the U.S. Census and now comprise more than one percent of the U.S. population (SAALT, 2012).

\section{Our Voices and Positionalities}

In our approach to this project, we reflected that our experiences as educators, researchers and students (in the U.S, Hong Kong, India, Pakistan and Germany) positioned schools as sites of, at times, perilous attitudes and behaviors, and at other times, possibility, hope and transformative learning. The three authors knew each other from our affiliation to Teachers College, Columbia University: Monisha Bajaj as a professor there at the time this project was initiated, Ameena Ghaffar-Kucher as a graduate of the doctoral program and Karishma Desai as a doctoral student. As South Asians in the U.S., we also had different vantage points: Bajaj, a 
second generation Indian-American who grew up on the West Coast with Sikh and Hindu heritage; Ghaffar-Kucher, a Pakistani Muslim who migrated to the U.S. for graduate studies, and who had previously lived in Asia and Europe; and Desai, a second-generation Indian-American raised in a large Hindu Gujarati community in the Midwest. Our intersecting experiences, as described below, shape how we came to the project, and detail the work we carried out as a team. Below, we each briefly shift into first person to underscore our individual narratives and investments in the project.

Monisha Bajaj: I moved to New York City two weeks before September 11, 2001. As the horrific events of 9/11 were unfolding, I found myself volunteering at the armory where services were being centralized: 'missing' posters lined the fences, donations poured in that we volunteers helped sort and family members (like the Urdu, Hindi and Bengali-speaking ones I clumsily helped translate for with my limited proficiency) were bringing in items with DNA— like toothbrushes and combs - to match with the body parts recovery workers were finding in the rubble to give closure to loved ones. A few months later in 2002, I began partnering with an organization for South Asian workers based in Queens. During this time, post-9/11 policy shifts-like the draconian "special registration" process for men from Muslim-majority countries - broke up thousands of families through massive round-ups and deportations. The multi-ethnic and diverse experiences of New Yorkers were slowly being erased and manipulated for political purposes to justify military actions abroad and enact legislation at home that eroded civil liberties.

Ameena Ghaffar-Kucher: I arrived in the U.S. a year before $9 / 11$ to begin my graduate studies. Prior to that, I had lived in Hong Kong, Pakistan and Germany. Though race and racism had played a role in my everyday lived experiences (particularly in Hong Kong), nothing 
prepared me for the racism in the post-9/11 period. Though Muslims had always been viewed with some trepidation in the U.S., attitudes towards Muslims (and brown people more generally) drastically changed almost overnight. Determined to learn more about the Muslim American experience, I began conducting research with South Asian and Muslim youth, working in particular with Pakistani high school youth in New York. Through their stories, I learned of the mundane micro-aggressions and outright racism that seem to color their everyday educational experiences.

Karishma Desai: My story is a reflection of the kinds of experiences that many South Asian American children endure in which I experienced frequent encounters of otherness. Despite my attempts to escape her lemon-colored comb every morning, my mother would insistently secure my shoulders in-between her knees, and braid my hair tight with coconut and bhringraj oil, repeating its countless benefits. Before leaving for school, I would sneak into the bathroom and quickly dab off as much oil as I possibly could from my scalp. And every morning, Jeff who sat behind me in Mrs. Cheney's third grade class would declare that my efforts had failed, "Ewww! What is that smell?" he would loudly whisper to his friend Matt behind him. At recess, Jeff and Matt would chase Ekta and I yelling, "Hindu dot! Hindu dot! Hindu dot!" They had made it their job to point out my differences, and mark my foreignness. Although I attended elementary school in one of the most multi-ethnic districts in the country, I frequently experienced xenophobic bullying. The lingering shame oriented my curriculum and pedagogical commitments later as a classroom teacher.

Monisha Bajaj: I initiated our team coming together in 2012 after the tragedy in Oak Creek, Wisconsin. The thought of immigrant communities seeking solace in worship at a Sikh temple, not unlike the one in California that I attended as a child, only to be gunned down by a 
self-proclaimed white supremacist targeting those whom he perceived to be Muslims, was terrifying and heartbreaking. The starting point of this project was thus the desire to interrupt hate despite the many directions that it flows. We knew that seeds of this xenophobic racism were either being planted in schools or ignored as they continued to be nurtured by extremist forces, impacting the everyday experiences of 'brown' children and youth.

In designing the curriculum, we considered what we wanted educators and learners to take away. Two enduring understandings especially compelled us: 1) xenophobic racism against South Asians in America has a long history that manifests in micro-aggressions, bullying and hate crimes; and 2) our migration stories as Americans have common themes and struggles (despite racialized differences), and, when we are aware of these historic commonalities, we can develop greater empathy and the capacity to become allies. As South Asian Americans, our positioning as model minorities (Iyer, 2015; Prashad, 2005) has sometimes obscured the insidious visceral effects/affects of historical and present day manifestations of xenophobic racism.

Taken together, our personal experiences and commitments form the basis for this project guiding our analysis and engagement with existing resources and scholarship to our development of the curricular resource packet as an intervention to promote greater awareness, understanding and solidarity.

\section{From Macro to Micro: Where Xenophobia meets School Bullying}

Current literature on bullying frames it as primarily an inter-personal phenomenon and one that can be corrected through behavioral approaches (Olweus, 1994; Sharp \& Smith, 2002). In the U.S., nearly 20 percent of elementary school children report being bullied with numbers 
declining to about 10 percent of youth in high school (Luxenberg et al, 2014). Bullying behavior has been defined as repeated and intentional abuse in a social or institutional setting. It can create or result from imbalances of power, and manifests differently in distinct social and cultural contexts (Sharp \& Smith, 2002). The most common discourses about bullying in the United States delineate between the "bully," "the bullied" and "bystanders" (Olweus, 1994), with some intervention efforts seeking to cultivate "upstanders" who serve as allies (Facing History \& Ourselves, n.d.).

Much of this literature has been influenced by psychological approaches (Olweus, 1993), treating bullying as individual (albeit often horrific) acts to be stopped through greater oversight and zero-tolerance policies (Stein, 2007). Conventional bullying literature and interventions neither consider how larger discourses, media narratives and discriminatory policies shape actions, nor consider extensively the role of teachers and schools in perpetuating or permitting bullying. Further, there is little mention of macro-level or structural forces, such as racism or Islamophobia, in scholarship or policy documents on bullying.

Bullying in schools often reflects social dynamics and bias embedded in sociocultural contexts within which schools are situated. All forms of bias-based bullying broadly, and xenophobic bullying specifically, we assert, require attention to the micro-, meso- and macrolevels to adequately understand its causes, dimensions of its occurrence and to effectively design strategies to counter it. 


\section{Figure 1: Levels of Analysis to Understand Xenophobic Bullying}

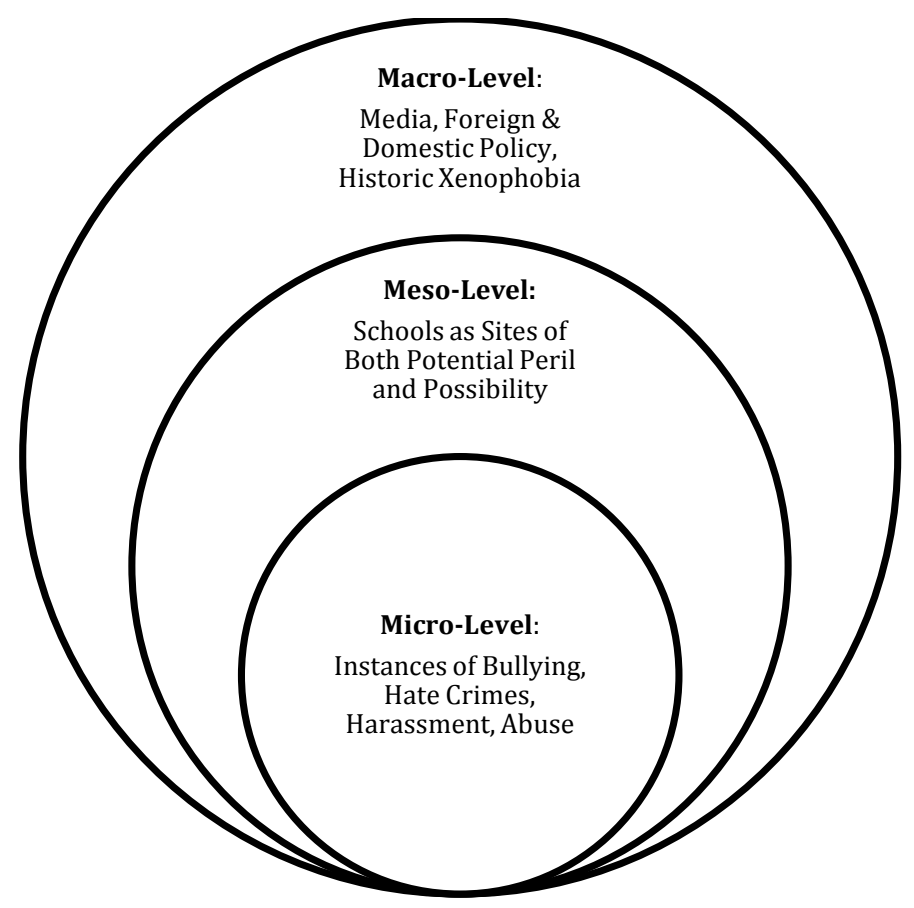

As mentioned in the introduction, our rationale for addressing the xenophobic bullying of South Asian American youth stemmed from its increasing incidence: more than half of all Asian American youth report being bullied (Hong, 2013), the highest percentage of any ethnic group surveyed, with even higher numbers for South Asian American youth [up to 75 percent (Coker, 2013)]. The majority of Sikh young men reported being harassed, taunted or intimidated because they wear a turban - a noticeable signifier of difference. These young men are often believed to be Muslim and their harassment exemplifies the pervasive Islamophobia and xenophobia targeting youth from South Asian communities, irrespective of their actual religious background.

Prevailing Islamophobia across the U.S., facilitated by one-sided media narratives, extensive surveillance of Muslim communities (Ali, 2014) and misinformation about Muslim populations, have resulted in a significant increase of bullying against South Asian American youth from a variety of religious, national and ethnic backgrounds (Coker, 2013; Sacirbey, 
2013). This is evidenced not only by numerous stories in the media, ${ }^{6}$ but also data collected by advocacy groups and think tanks such as South Asian Americans Leading Together (SAALT), the Council of American Islamic Relations (CAIR), and the Institute for Social Policy and Understanding (ISPU), as well as documented in scholarly research (see Ahmad \& Szpara, 2003; Ali, 2014; Ghaffar-Kucher, 2012; Sirin \& Fine, 2008). A report by ISPU suggests that Muslim American children and youth are bullied for reasons that are not typical (e.g., physical appearance, ability level and popularity), but because of their ethnicity and religion and the belief that they pose a threat to the "American way of life" (Britto, 2011).

\section{Situating Islamophobia at the Macro-Level}

The construction of Muslims in the Western imagination has been a historically racialized process - the assumption being that Muslims come from the "orient" and are typically brown skinned. Junaid Rana (2011) links the "moral panic" after 9/11 vis-à-vis populations of South and West Asian descent to the xenophobic discourses and policies of decades past, terming it an "Islamic peril." Drawing on critical race theory, he discusses how fear and insecurity, coupled with media representations and restrictive policies, have advanced the "consolidation of a Muslim racial formation post-9/11" that conflates "Arabs and South Asians...into the racial figure of the Muslim" (p. 93). Signifiers of this "racial figure of the Muslim" include brown skin, turbans, hijabs, accents and beards, underscored by mainstream perceptions of illegality and foreign-ness (Rana, 2011).

We find this concept of 'racialized Muslim' useful to our project because it supports our

\footnotetext{
${ }^{6}$ At the time of writing this essay, the 2016 presidential race with some candidates' controversial positions about banning Muslim migration had led to an exponential increase in bullying, hate talk and hate crimes against Muslims and those perceived to be Muslim.
} 
argument that those perceived to be Muslim are unified by this form of xenophobia in terms of the violence directed at them. In only two months after the tragic 9/11 attacks, thousands of people were assaulted, 19 killed, including South Asians, Arabs, Latinx, Native Americans and others with "Muslim-like" features (Grewal, as cited in Rana 2011, p. 51). From 2001 to the present, hate crimes have 'skyrocketed' against anyone perceived to be Muslim, though these are usually documented and responded to by specific communities rather than uniting among groups that are affected by Islamophobia.

Contemporary violence (inclusive of bullying) and insecurity comes from the juxtaposition of racism, neoliberalism and neo-imperial wars, and these feelings are felt within realms of social life that seem unrelated to state power (Grewal, 2014). The terrain of America's War on Terror is infused with cultural constructions such as "terrorist threats" and "alien civilization," that legitimate racial profiling policies which target populations based on U.S. foreign policy anxieties (Maira, 2009). These constructions are related to cultural citizenship (Ong, 1996) and the perception that Muslims are pre-modern, anti-democratic and, therefore, a threat to liberal Western society (Ali, 2014) and ideals of humanness (Asad, 2015).

Per Rana (2011) and other scholars (Abu El-Haj, 2015; Maira, 2009), we identified three larger tropes shared between historical forms of xenophobia and present-day discourses of unequal citizenship/humanity that construct macro-level discourses of Islamophobia. The first trope draws on Rana's notion of 'Islamic peril' that produces fear and a sense of insecurity when around individuals perceived to be Muslim. For example, the regular accounts of brown-bodied individuals being removed from planes for speaking Arabic, ${ }^{7}$ wearing a t-shirt with Arabic

\footnotetext{
7 The Daily Beast. (Producer). (2015, January 10). Arabic Speaking Men Barred From Flight. Retrieved from http://www.thedailybeast.com/cheats/2015/11/20/philly-men-pulled-off-flight-for-speaking-arabic.html
} 
letters,${ }^{8}$ or carrying a breast-pump perceived to be a bomb, ${ }^{9}$ highlight the routine everyday interactions that render brown bodies dangerous.

The second trope, which has deep historical roots as well, is that of a 'clash of civilizations' (see the misguided and arguably xenophobic work by Samuel Huntington, 1996). The supposed Christian nature of the U.S. - asserted particularly by those on the political rightis often highlighted as a form of incompatibility with Americans of other faiths, despite the fact that Muslims have been in the U.S. from its genesis as a nation (Ghaneabassir, 2010).

The third trope that contributes to a larger climate of Islamophobia is that of 'perpetual foreign-ness' (Maira, 2009). No matter the length of time individuals and families have resided in the U.S., they are perceived to be foreign, dangerous and unaccepting of American values. These larger tropes influence the milieu in which schools operate, particularly when lessons in critical media literacy and historical information that attends to geopolitics are notably absent.

We argue that the particular brand of xenophobic bullying our curriculum seeks to address results from larger historical and institutional forces that accentuate these problematic tropes. These tropes are continuations of colonial discourses that have been exacerbated in the post-9/11 period in which anyone perceived to be Muslim is seen as a threat to security. Thus, we believe that it is important to re-center a structural lens - one that conventional literature on bullying has neglected to employ — that allows more nuanced analyses of individual expressions of bias, as the next section outlines.

\footnotetext{
${ }^{8}$ BBC (Producer). (2006, January 5). Arabic T-shirt sparks airport row. http://news.bbc.co.uk/2/hi/5297822.stm

${ }^{9}$ RT. (2015). Suspicious threat: Sikh woman's breast pump causes terror alert before Delta flight. https://www.rt.com/usa/324687-sikh-mother-flight-terror-alert/
} 


\section{The Curriculum Development Process: Understanding Islamophobia at the Micro-Level}

In seeking evidence for our curricular intervention, we reviewed scholarship on the experiences of youth from various backgrounds targeted by xenophobic bullying (rooted in Islamophobia, whether or not the victims were Muslims); drew from our own experience as educational scholars and practitioners; and interviewed researchers who worked in this area. While traditional bullying scholarship distinguishes between physical, verbal, social/emotional and cyber forms of bullying (Olweus, 1993), we found that when the bullying target was perceived to be Muslim, the types of behaviors (while accompanying all the forms above) took on particular dimensions that followed along the three larger tropes we identified earlier: 'Islamic peril,' 'clash of civilizations' and 'perpetual foreigner.' Additionally, traditional bullying literature posits that such behaviors happen between peers and can be interrupted by student mediators or 'upstanders' who speak up. Here, we found a troubling trend: many of the instances of bullying experienced happened with the knowledge of teachers or with them participating in some cases.

Based on our review of dozens of incidents, we found several types of xenophobic bullying that South Asian American youth repeatedly experience that are all integrally linked to the three tropes introduced earlier. ${ }^{10}$ First, name -calling and verbal bullying is a common form of bullying in conventional scholarship, but takes on a unique form when the targets are assumed to be Muslim, such as being called a "terrorist," "raghead," "diaperhead," or "towelhead" and being threatened with nativist violence. A second domain of xenophobic bullying includes

\footnotetext{
${ }^{10}$ To develop these domains, we culled examples of xenophobic bullying from reports, websites, talking with researchers about their work whenever possible (e.g., Ghaffar-Kucher, 2012; Maira, 2009; Subramanian, 2014), our own observations as educators and policy documents; we then sat together to categorize the domains under which incidents fell. We subsequently delineated the historical and macro-level frames that outlined the context in which xenophobic bullying takes place, identifying tropes that shaped South Asian youths' experiences of bullying.
} 
physical assaults and intimidation; regular incidents included taunting, violently removing hijabs or turbans (in some cases setting them on fire), forcibly cutting someone's hair off, and other physical assaults. The third domain could include verbal or physical forms of bullying, but had a specific religious-based character: youth reported bullying behaviors directed at them indicating that non-Christians are going to hell, that they believe in false Gods, they cannot be American if they are not Christian, ridicule of their religions and defilement of religious objects. We identified a fourth domain of xenophobic bullying that included attacks on families and communities, differing from conventional bullying scholarship that often only focuses on schools. Routine examples of bullying in this domain included statements such as "go back where you came from"; physical damage to property (throwing of eggs, lighting fires, vandalism/graffiti with derogatory statements); attacks at school on students' property, and also on their homes and places of worship. The last domain of xenophobic bullying that we identified related to ridicule and taunting based on the types of foods students ate, their appearance, and how they dressed or smelled. By analyzing actual incidents and understanding the trends and domains in which youth experienced bullying, we were able to ground our curriculum in real-life incidents - or experiential knowledge, as critical race theorists of education have advocated (Yosso et al., 2001).

Through mapping larger understandings of bullying onto the types of racialized incidents that brown-bodied South Asian Americans routinely face, these domains above informed the curricular intervention we developed by focusing on the most common forms of bullying and harassment faced by South Asian American children and youth. While conventional bullying literature proved insufficient for our project, we did resonate with its belief that educators, parents and communities can play an important role in intervening and preventing bullying 
through the creation of safe school environments (Olweus, 1993; Wang et al., 2009). Thus, this project considered schools as not only potential sites of misinformation, but also possible sites of transformation.

Figure 2: Intersections of those Commonly Affected by Islamophobia in the U.S. ${ }^{11}$

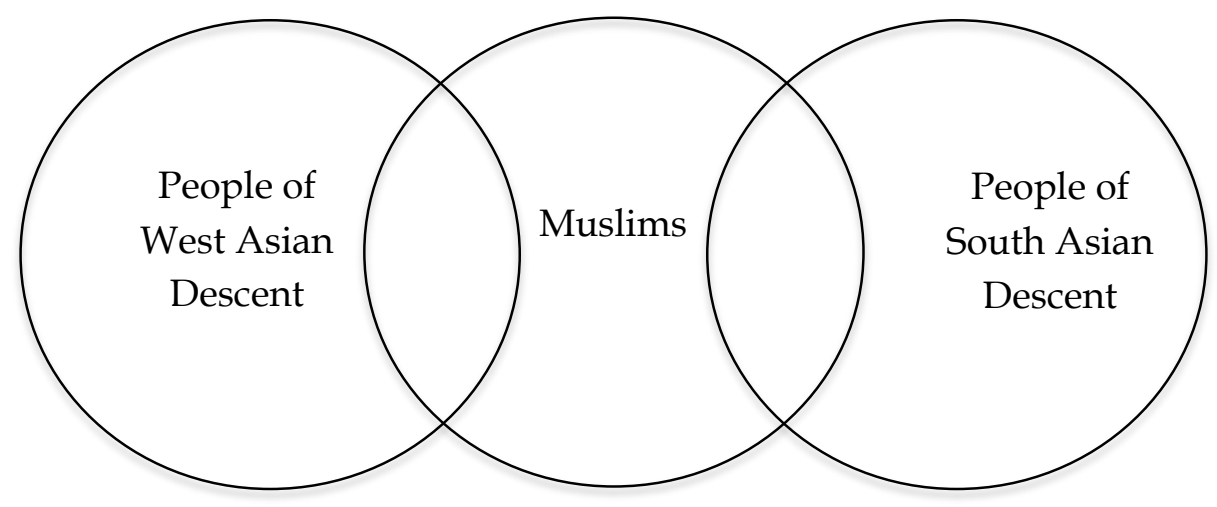

In our process, we underwent various stages that were overlapping and complementary.

We did a comprehensive review of existing documents to create the domains that we discuss above. We also drew key insights from critical race theory in education for our curriculum, namely: (1) understanding the permanent centrality of race and racism and its structural nature in the U.S. at all levels (Bell, as cited in Yosso et al., 2001, p. 91); (2) incorporating the use of storytelling and experiential knowledge (woven throughout the lessons) as curricular resource; (3) "envision[ing] social justice as the struggle to eliminate racism and other forms of subordination while empowering groups that have been subordinated" (Solórzano and Delgado Bernal, 2001, p. 91); and (4) linking the micro-, meso- and macro-levels in understanding the

\footnotetext{
${ }^{11}$ According to latest Census figures available, people of West Asian (the census uses the term "Middle Eastern") descent total about 2.5 million; Muslim Americans 3.3 million; and people of South Asian heritage 3.4 million, with important overlaps between these groups in terms of national origins and religions.
} 
complex ways that racialized discourses are deployed, lived, resisted and transformed in and around schools (Abu El-Haj, 2015; Taylor, Gillborn \& Ladson-Billings, 2009).

The 'social justice imperative' of critical race analyses of education (Solorzano \& Delgado Bernal, 2001) led us to seek out community partners, such as the New York City-based non-profit, SAYA (South Asian Youth Action), and the national advocacy network, South Asian Americans Leading Together (SAALT). SAALT partnered with us to broaden the distribution of the curriculum and to enable the input of advocates addressing issues facing South Asian Americans. We also drew extensively from SAALT reports and training materials utilized with college-level students.

In the curriculum, we also highlight historical forms of xenophobia as an antecedent to current forms of Islamophobia. To that end, we approached the South Asian American Digital Archive (SAADA) and received permission to use images in our lessons they had been compiling to offer primary sources to link students to the lived experiences of South Asian immigrants and historical racialized constructions from the 1700 s to the present-day.

Working in tandem with educators, activists, advocates and community members, the final product, a 90-page open-access curricular resource pack, offers educators resources for addressing xenophobic bullying and racism directed at youth of South Asian descent in U.S. schools.

\section{Curriculum as Intervention: Mediating Islamophobia at the Meso-Level}

In this section we argue that the normalization of xenophobic bullying is based on ideas of which bodies are seen as fully human and which bodies are seen as sub-human (Butler, 2004; Weheliye, 2014; Asad, 2015). We offer the curriculum as an intervention to counter this by 
historicizing this specific form of bullying and engendering spaces of interconnectedness and thereby humanizing the "Other." As mentioned earlier, race has been a dominant marker of South Asian, West Asian and Muslim "Otherness," and these racist portrayals have persisted since colonial times (Prashad, 2005; Said, 1994). South Asian American youth become objects of bullying and violence because their racialized brown bodies are perceived as threats. In seeking to strengthen the empathic capacity of students, educators and schools, we also had to extend the frame of who is regarded as "American" and "human." The bullying we seek to counter through this curricular intervention is a part of, and rooted in this process that defines and delimits who is fully human. Anchored in a larger narrative, xenophobic racist bullying underscores the disposability and precarious status of certain lives (Butler, 2004).

In what follows, we describe the curriculum and explain how this intervention seeks to counter the tropes presented earlier and the idea that some have full-human status and others do not through learning opportunities that offer common ground and enable students to make connections between migration stories, develop empathy and act as allies.

\section{The Curriculum}

Educators, while sometimes part of reproducing dominant narratives of xenophobia and bias in schools, often seek ways to intervene when they see situations of bullying or injustices in their schools. This curricular packet sought to offer educators and school staff with resources and tools to start conversations, support targeted students in locating themselves and their histories in the U.S. and foster understanding and awareness in school communities about fellow students who are perceived to be "brown threats" (Rivera, 2014) rather than peers of equal value. We acknowledge that educators concerned with social justice may be more likely to gravitate towards such a curriculum, as may educators who work with South Asian students. As such, this 
curriculum presupposes that the classrooms it will be utilized in have some contact with or familiarity with South Asian American communities: census data reveals that South Asians have settled in all 50 states, with significant populations in Northern and Southern California, the tristate New York-New Jersey-Connecticut area, and the Washington, DC, Chicago, Detroit and Houston metropolitan areas (SAALT, 2012).

Given the rising and persistent cases of Islamophobia manifested through xenophobic bullying in schools, we also felt a sense of urgency since schools are the third most common site for the perpetuation of hate crimes in the U.S. (Greene et al., 2013). We sought to equip educators with resources and tools to create awareness and prevent instances of bullying and intimidation — whether from peers or teachers. Insights from critical race theorists in education informed our design and implementation of the curriculum by historicizing issues of xenophobia; we also used real events in role-play or case study scenarios with the aim of building awareness, recognition (for those who may be undergoing similar acts of bullying) and empathy/understanding.

The curricular resource packet consists of an introductory note for educators, six lessons and an extensive list of further activities and resources which offers educators an entry point to talk about bullying, harassment, hate and violence. In Table One, we outline the lesson sequence including the activities included (all were participatory and interactive in nature). Several of the lessons drew on insights from critical race theory in education; for example, lessons one and five posit race and racism as central frames for understanding the South Asian immigrant experience, while lessons two, four, and six incorporate the use of counter-stories that seek to spark solidarity and a commitment to social justice. All of the lessons and the curricular pack as a whole draw from critical race analyses by historicizing xenophobia and not presenting it as 
merely a post-9/11 phenomenon, but rather one with deep roots and diverse manifestations from the 1700s forward.

Table One: Table of Contents for Resource Pack

\begin{tabular}{|c|c|c|}
\hline & Topic & Educative Goal \\
\hline 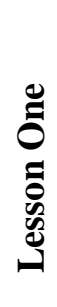 & $\begin{array}{l}\text { South Asians in the United States } \\
\text { Activities: } \\
\text { 1. Timeline of Images \& Facts about South } \\
\text { Asians in the U.S. } \\
\text { 2. Glossary Activity with key terms and } \\
\text { definitions }\end{array}$ & $\begin{array}{l}\text { Historicize South Asian presence in the U.S. } \\
\text { from the } 1800 \text { s onward. } \\
\text { Introduce key terminology about } \\
\text { Islamophobia, xenophobia \& bullying. }\end{array}$ \\
\hline 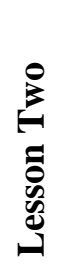 & $\begin{array}{l}\text { Everyone's Migration Story } \\
\text { Activities: } \\
\text { 1. Mapping migration stories } \\
\text { 2. Timeline of Key Moments in U.S. } \\
\text { migration of various groups }\end{array}$ & $\begin{array}{l}\text { Place xenophobia in historical perspective. } \\
\text { Expand frame of "American" by examining } \\
\text { migration more broadly, including learners" } \\
\text { families. }\end{array}$ \\
\hline 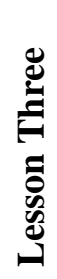 & $\begin{array}{l}\text { Bullying Intersections } \\
\text { Activities: } \\
\text { 1. Discussion of Bullying broadly } \\
\text { 2. Real life Xenophobic Bullying Examples } \\
\quad \text { Role Play }\end{array}$ & $\begin{array}{l}\text { Build empathy by providing information } \\
\text { about xenophobic bullying experienced. } \\
\text { Develop capacity to identify bullying } \\
\text { incidents. }\end{array}$ \\
\hline 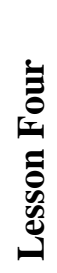 & $\begin{array}{l}\text { Building Empathy } \\
\text { Activities: } \\
\text { 1. Learn about Oak Creek, Wisconsin } \\
\text { Shooting, read testimonies of survivors } \\
\text { 2. Write letter to survivors of the tragedy }\end{array}$ & $\begin{array}{l}\text { Build knowledge about the dangers of } \\
\text { Islamophobic attitudes. } \\
\text { Foster solidarity with victims of violence. }\end{array}$ \\
\hline 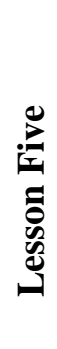 & $\begin{array}{l}\text { The Racialization of South Asians, Past } \\
\text { and Present } \\
\text { Activities: } \\
\text { 1. Examine images and texts of xenophobic } \\
\text { incidents from } 1907 \text { to the present } \\
\text { 2. Link past forms of xenophobia to the } \\
\text { present }\end{array}$ & $\begin{array}{l}\text { Address roots of xenophobia and place it in } \\
\text { historical perspective. } \\
\text { Foster knowledge, empathy \& solidarity; } \\
\text { ability to identity xenophobic attitudes \& acts. }\end{array}$ \\
\hline
\end{tabular}




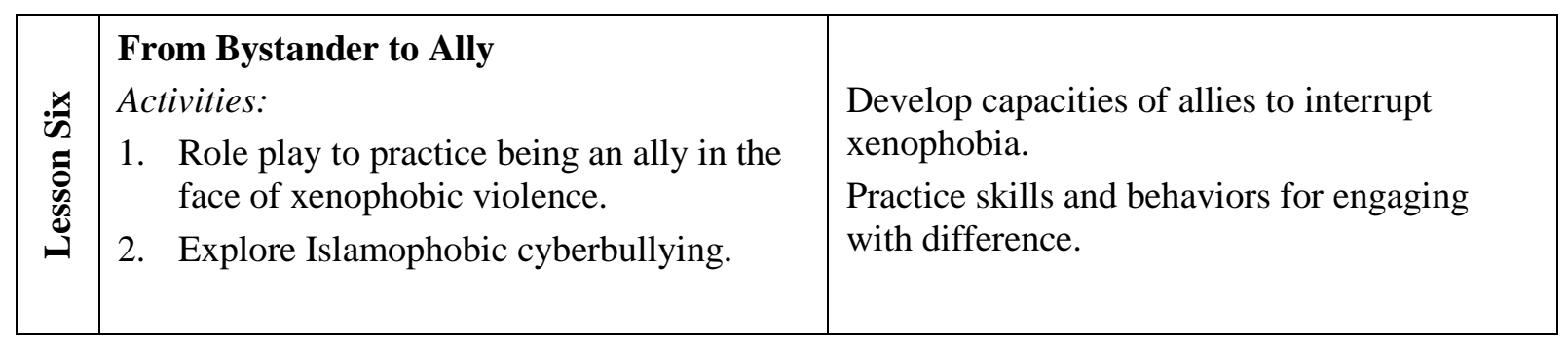

The resource packet had objectives that could have extended beyond six lessons, as noted by the expansive educative goals in Table One. The curricular intervention intended to provide information about the diversity of South Asians and their experiences in the U.S., and to unsettle three misconceptions contained in the larger Islamophobic tropes discussed earlier in the essay: Islamic peril, the clash of civilizations and the perpetual foreigner. First, the trope of Islamic peril positions individuals with brown skin as enemies of the state that produce fear and insecurity. Our lessons (specifically \#1 and \#3) counter this by explicitly defining and problematizing xenophobic bullying. The lessons also highlight deep civic engagement in the U.S. by South Asian Americans to counter this narrative of 'foreign enemy' and 'threat' (notably, we include information about the first U.S. Congressperson of Asian descent who was a Sikh immigrant, Dilip Singh Saund, elected in 1957 in California). The tropes of the clash of civilizations and perpetual foreigner, while the root of much violence, are sadly, not new. A core goal of the curricular packet was to historicize discrimination against South Asians as not just a post-9/11 phenomenon, but one that has existed since the $18^{\text {th }}$ century when immigrants from South Asia first arrived, though perhaps more visible now with new ways of sharing information. The lessons together sought to provide historical information about the lived realities of immigrants past and present. Furthermore, by asking prospective learners to attend to their own family's migration stories, we sought to destabilize the attachment of foreignness with brown 
bodies. For example, lesson two underscores how the social racial formation in the U.S. has shifted over time marking different communities as 'alien' and undesirable.

The use of primary sources allowed us to provide learners with a glimpse into actual examples of xenophobia. For example, in lesson five, the following image (Figure Three) and an excerpt from the newspaper enable students to historicize xenophobia against South Asians. Historical "Othering" is thus juxtaposed with present day xenophobia folded into bullying acts and language illustrating the commonalities in these violent narratives. The article describes how, in response to a "tide of turbans" and "dusky Orientals," a nativist mob violently attacked South Asian millworkers and their families in Washington state driving them out of town. The newspaper editorial notes the horrific violence, but concluded that, "the departure of the Hindus [outdated term for all South Asians] will leave no regret." It further states, "they are repulsive in appearance and disgusting in their manners... The Hindu is a detriment to the town" (Seattle Civil Rights \& Labor History Project, n.d.). 
Figure 3: Newspaper Article from September 1907 on Bellingham Riots

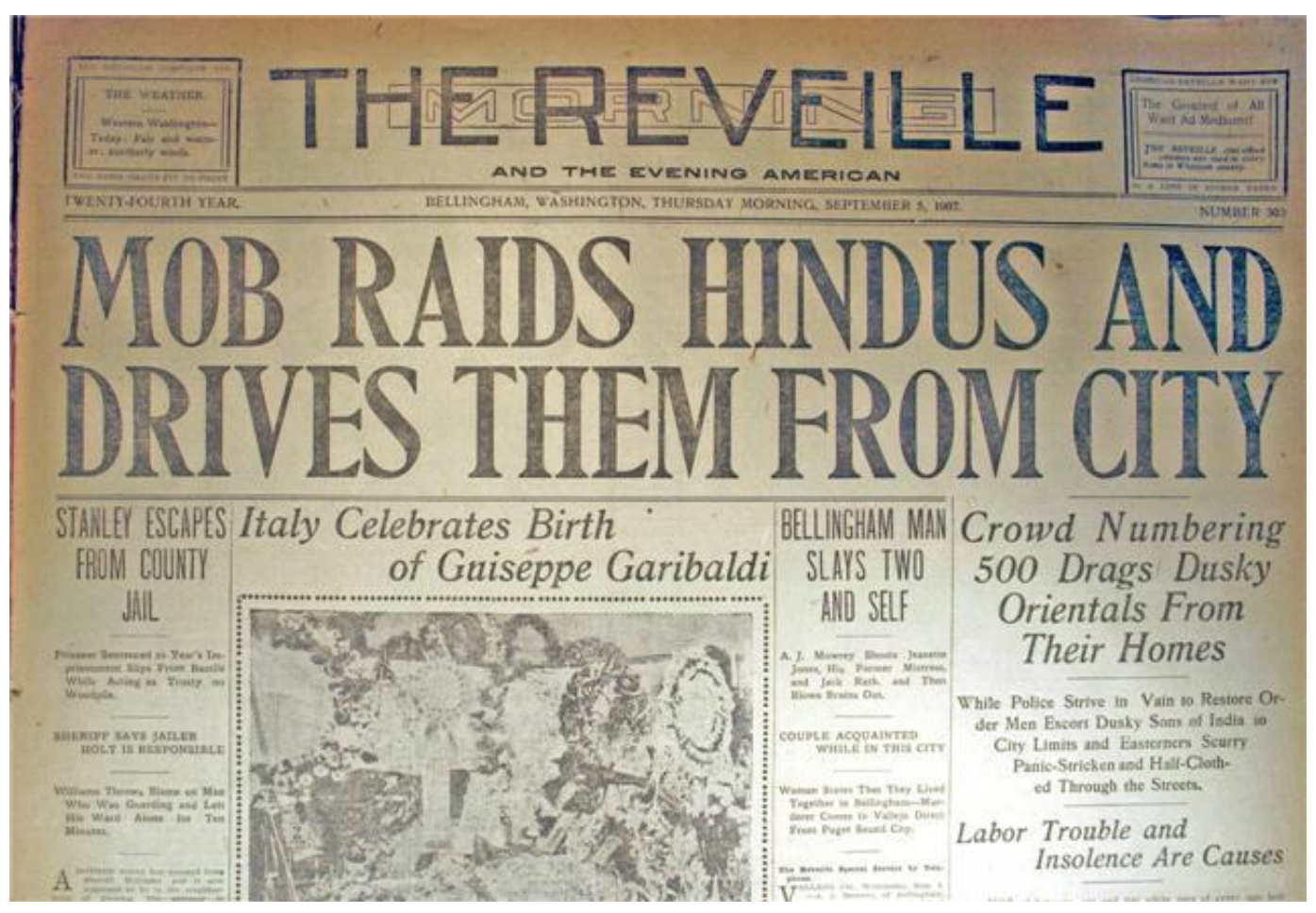

After analyzing the newspaper image and editorial from 1907, lesson six asks students to explore present-day examples of cyber-bullying drawing on the historical information, definitional understandings of Islamophobia and xenophobia and information about what being an ally means. 
Figure 4: Excerpt from Lesson Six

(image created by the authors using real life examples that emerged during our background research)

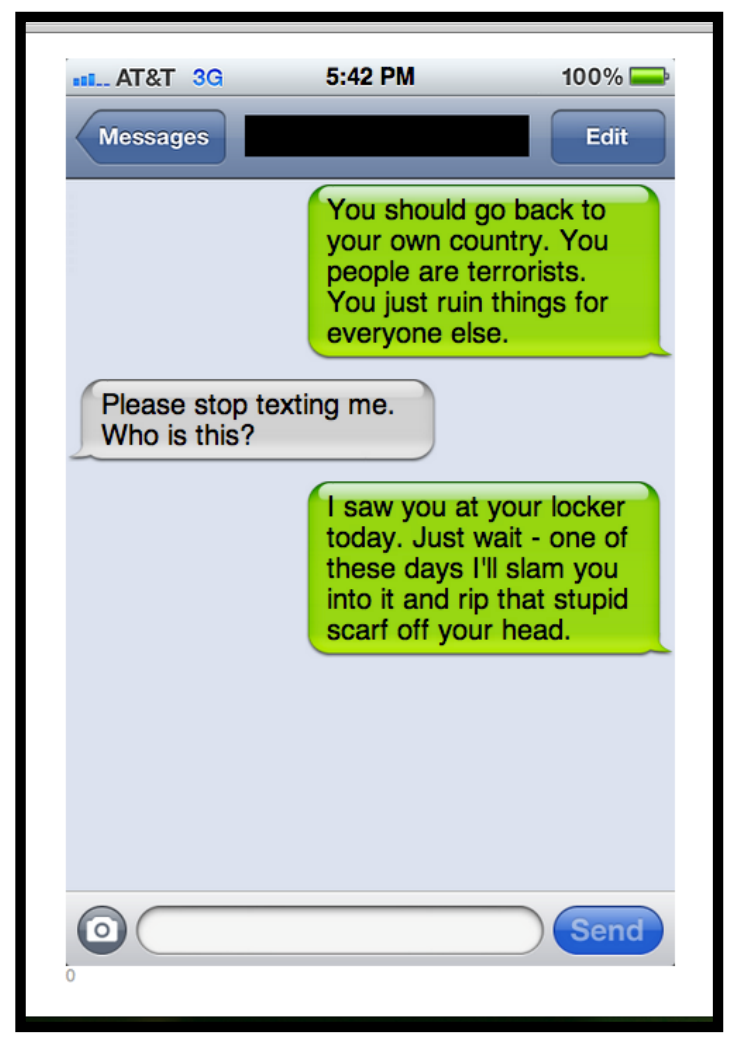

By moving between past and present, macro to micro, we sought to offer students and teachers - given many reports of their role in allowing or participating in forms of xenophobic bullying - a complex yet accessible introduction to the ways in which xenophobia plays out and can be countered in schools. The links between blatantly racist historical events and everyday practices offers students a chance to make connections, engage in critical media literacy and develop an understanding of experiences of targeted students (or recognize such bullying as 
abusive in the case of students experiencing it). The six lessons and further resources worked together to offer many points of entry and new information to teachers and students.

\section{Reflections}

The intention of the curriculum was to address xenophobic bullying by unsettling the tropes of Islamic peril, clash of civilizations and perpetual foreigner, and enriching students and teachers' limited knowledge of South Asian Americans. To do this, we designed the following essential questions to frame and anchor our curricular intervention:

- How does understanding historical narratives of South Asia and South Asian American history lead us to comprehend, unpack and undo current views and forms of xenophobic racism?

- How do deeper understandings of complex and diverse community and individual histories help us build empathy and act as allies?

- How do we build more inclusive schools and communities?

The lessons were crafted with the hope that educators and students would begin to grapple with these questions, and move beyond mainstream discourses often embedded in school-based instruction, examine new perspectives and question dominant assumptions. Certainly, the curriculum complicates and disrupts the construction of contemporary Islamophobia as it moves through historical timelines, shared migration narratives, stories of xenophobic bullying and comparative explorations of targeted racism across time periods.

However, lessons about historical and contemporary global geopolitics would have furthered our goal of deconstructing Islamophobia. Educators and students might understand the reasoning that infuses these problematic discourses with added curricular material that teaches analyses of the historic construction of the "racialized Muslim" (Rana, 2011) and present-day 
reconfigurations of these colonial tropes. Lessons could have also furthered a better understanding of contemporary global conditions such as the international war on terror that produces Islamophobia.

We recognize the limits and uncertainties of the ambitions embedded in the essential questions that drive this curriculum. We hope that historicizing both the migration of South Asian Americans as well as the configuration of these bodies as threatening and feared "Others" in the mainstream imaginary will complicate constructions held by educators and students. Yet, this same historical condition informs the deep-rootedness of normalized ideas of "Otherness" in the national consciousness. Secondly, while we see empathy as a productive feeling with the potential to support student understandings of the precarities faced by children that encounter xenophobic bullying, education scholars have recognized the limitations of empathy in social justice curriculum (Boler, 1997). For instance, Megan Boler (1997) illustrates how the desire to generate empathy or full identification with the other in multicultural curriculum often maintains passivity and fails to interrogate relationships of power. Two particular moments in our lessons seek to build empathy explicitly: a lesson on shared migration histories and a lesson that asks students to engage the testimony of Harpreet Singh Saini who lost his mother in the Oak Creek tragedy. The lesson on migration histories considers historical context and asks students to engage their own assumptions regarding "Who is an American?" and thereby seeks to attend to power dynamics. To further students' critical reflection on their own positionality in the present condition, we could integrate provocative and risky questions to guide the reflective letter in response to Harpreet's testimony. This might produce what Boler (1997) calls a "testimonial reading" that implicates the reader (Boler, 1997, p. 263).

However, given that this open-access document may be picked up and utilized without 
much training or particular background in critical pedagogies, we made a decision to make the lessons as accessible as possible for interested educators. We thus also recognize the limitations of this and any curricular intervention in addressing macro level discourses, policies and historical conditions. At the same time, we see the potential - unsettling normalized notions might alter the ways in which the teachers and students affected by the curriculum engage with communities attached to these markers of difference and how they consume biased media discourses and images.

Moreover, the curriculum would have benefitted from pilot lessons and ongoing discussions with students and educators during the time of its development. We had more flexibility and ability to partner with community groups than most educators do when creating curriculum given our position in the academy that facilitated such relationships; that said, with more time and planning, we could have engaged classroom teachers and students more in the process, and piloted the curriculum in multiple sites, evaluating the implementation and revising the curricular resource accordingly. Greater input would have allowed us to provide suggestions on how to map this curriculum onto teachers' plans, specifically where in the curricular sequence such lessons, in whole or in part, might fit. While different mandates regulate teacher curriculum, such guidance would make the incorporation of this curriculum more feasible beyond the brief mention we provide in the curricular resource pack of how it aligns with Common Core standards (p. 5). As it stands, the curricular packet is our 'first-cut' at information and understandings we believe could begin to destabilize Islamophobic sentiments and promote greater empathy, but such an assertion has not yet been explored in practice. Given that the curriculum is largely a yet-untested innovation, this essay serves as an invitation for others to 
engage with it, assess its impact, join in conversation discussion and suggest additions and modifications to the curriculum.

Since the curricular resource was launched in April 2013, it has been disseminated widely to educators, activists and policymakers. Through our own networks and contacts as well as those of the partners on this project (SAALT primarily), youth training programs for South Asian Americans have used the curriculum, it has been introduced as a text in teacher education courses (at City College of New York, New York University, the University of MassachusettsAmherst, among others), and has been circulated to teachers across the U.S. and Canada. In May 2013, SAALT worked with Representative Mike Honda, a Democrat from California who chairs the Congressional Anti-Bullying Caucus, to circulate the curriculum with a cover note about the importance of addressing bullying to his hundreds of fellow representatives in the U.S. Congress. The entire curriculum is online and freely accessible to any individual or group that seeks to use it in part or whole. ${ }^{12}$

Our team has conducted several workshops and trainings for educators and policymakers at different venues, including South Asian American advocacy meetings and several teacher educator conferences. In these workshops, we provide an overview of the rationale for the curriculum, examples of xenophobic bullying and then walk participants through a sample activity or two from the curriculum. Many participants have responded that it was powerful to learn about real-life examples of bullying as well as strategies to interrupt such practices. The next steps for this project would be to study any impact — intended or unintended — of the curriculum and engage in further teacher professional development.

\footnotetext{
${ }^{12}$ See http://saalt.org/wp-content/uploads/2012/09/In-the-Face-of-Xenophobia.pdf
} 


\section{Discussion \& Concluding Thoughts}

Through this project, we sought to 'speak back' to the bullying literature which, while acknowledging race or religion, lacks a structural analysis of how xenophobia impacts youth experiences. Conventional bullying literature provided insufficient frames for our analysis of the sometimes-harmful attitudes and roles of teachers in xenophobic bullying incidents, as well as tracing such attitudes back to larger discourses, media narratives and discriminatory policies.

Not only is the diversity among South Asian Americans rarely acknowledged, their experiences with bullying are infrequently understood. Our work with South Asian American communities, coupled with both academic and grey literature, suggests that xenophobic racism experienced by these youth is different from that of other immigrant youth as it is frequently related to the youths' (assumed) religious backgrounds. We posit that understanding the macrolevel formation of Islamophobia enables connections to the particular discourses that circulate and shape how youth experience bullying in schools. Schools do not exist in a vacuum, and the intersection of racism, xenophobia and Islamophobia seem to consistently be the root cause of this kind of bullying experienced by South Asian American youth. Efforts must understand what drives such bullying in order for it to be effectively addressed.

Although over 15 years have passed since September 11th, 2001, the repercussions felt by South Asian, West Asian and Muslim communities in the post-9/11 aftermath remain palpable. As these communities continue to grow, South Asian Americans face increasing hostility and surveillance as illustrated by various reports (SAALT, 2014). For example, we regularly hear about Islamophobic graffiti on mosques, Hindu temples and gurdwaras as well as violent assaults in and outside of schools. All of these are rooted in a larger matrix of racialized violence against brown bodies. 
South Asian American organizations along with several advocates of various immigrant justice organizations have sought to act in solidarity with other religious communities facing extremist violence informed by their own experiences with such violence. Sikh communities have stood with Muslims even amidst being the targets of Islamophobic violence (Young, 2016), and also African Americans after the horrific shooting at Mother Emmanuel Church in Charleston in 2015 (Delong \& Sachs, 2015). Alicia Garza, co-founder of the Black Lives Matter Movement, asked in an article following the Charleston Massacre, "Who taught Roof [the confessed shooter] to hate Black people, enough to kill nine of us, in a sanctuary?" (Garza, 2015). Similarly, some of the larger questions that guide our work as scholars and practitioners in education and that are infused into this project as well as our ongoing projects include: how can educators who encounter racist attitudes in their classroom work to foster respect for difference and equal rights in their school communities? How can schools be sites for transformative learning amidst dominant narratives and structures of inequality that reproduce racism and xenophobia? How is it possible that a child can go through the American educational system, graduate and come out a violent white supremacist?

Our curricular resource pack, In the face of xenophobia: Lessons to address the bullying of South Asian American youth, serves as one small intervention, an attempt to disrupt the consequences of these structures of inequality by unsettling the assumptions people have of South Asians in the U.S., bringing lived experiences of xenophobic bullying to the fore and casting possibilities of new forms of empathic understanding. While certainly not a panacea, our hope is that engaging with race in meaningful ways in the classroom, can offer transformative learning for students and educators that can interrupt the hidden and not-so-hidden curriculum of bias that leads to violence in and around schools. Humanizing the "Other" is the premise of 
education for social justice, peace and human rights. By offering a window into the experience of South Asian Americans_-and the often painful manifestations of violence youth in this community face — our goal is to encourage dialogues that increase empathy and expand notions of belonging and citizenship for these students who increasingly attend U.S. schools. 


\section{References}

Abu El-Haj, T. R. A. (2015). Unsettled Belonging: Educating Palestinian American Youth after 9/11. Chicago: University of Chicago Press.

Ahmad, M.I. (2004). A rage shared by law: Post-September 11th violence as crimes of passion. California Law Review, 92 (5).

Ahmad, I. \& Szpara, M.Y. (2003). Muslim children in urban America: The New York City school experience. Journal of Muslim Minority Affairs 23, 295-301.

Ali, A. (2014). A threat enfleshed: Muslim college students situate their identities amidst portrayals of Muslim violence and terror. International Journal of Qualitative Studies in Education, 27(4), 1243-1261.

Asad, T. (2015 October 20). Being Human: An interview with Talal Asad/Interviewer: H. Azad. The Islamic Monthly. Retrieved from: http://theislamicmonthly.com/being-human-an-interview-with-talal-asad/

Britto, P. (2011). Global Battleground or School Playground: The Bullying of America's Muslim Children http://www.ispu.org/content/Global_Battleground_or_School_Playground_The_Bullying _of_Americas_Muslim_Children\#sthash.raLVdu7v.dpuf

Boler, M. (1997). The risks of empathy: Interrogating multiculturalism's gaze. Cultural studies, 11(2), 253-273.

Butler, J. (2004). Precarious life. London: Verso Books

Cainkar, L. \& Maira, S. (2005). Targeting Arab/Muslim/South Asia Americans: Criminalization and Cultural Citizenship. Amerasia Journal, 31(3), 1-28.

Coker, M. (2013). Nearly Half of Muslim Students in California Schools Have Been Bullied in Some 
Way: Report. Retrieved from

http://blogs.ocweekly.com/navelgazing/2013/12/muslim_student_bully_californi.php

Delong, K. and Sachs, J. (2015). "We share the pain:” Sikh Temple in Oak Creek the site of candlelight vigil to pray for Charleston. Retrieved at http://fox6now.com/2015/06/21/sikh-temple-of-wisconsin-in-oak-creek-hostingcandlelight-vigil-for-charleston-shooting-victims/

Solorzano, D. \& Delgado Bernal, D. (2001). "Examining Transformational Resistance Through a Critical Race and LatCrit Theory Framework: Chicana and Chicano Students in an Urban Context." Urban Education, 36, 308-342

Facing History and Ourselves. (n.d.). Upstanders. Retrieved July 5, 2016, from http://outreach.facinghistory.org/pages/upstander

Flinders, D. J., Noddings, N., \& Thornton, S. J. (1986). The null curriculum: Its theoretical basis and practical implications. Curriculum Inquiry, 16(1), 33-42.

Freire, P. (1970). Pedagogy of the oppressed. New York: Continuum.

Garza, A. (2015). We Were Never Meant to Survive: A Response to the Attack in Charleston. In Truth-Out. Retrieved from http://www.truthout.org/opinion/item/31465-we-were-never-meant-to-survive-a-response-to-theattack-in-charleston\#

Ghaffar-Kucher, A. (2012). The religification of Pakistani-American Youth. American Educational Research Journal, 49(1), 30-52.

Ghaneabassir, K. (2010) History of Islam in America: From the New World to the New World Order. Cambridge: Cambridge University Press. 
Green, J. G., Felix, E. D., Sharkey, J. D., Furlong, M. J., \& Kras, J. E. (2013). Identifying bully victims: Definitional versus behavioral approaches. Psychological assessment, 25(2), 651-675.

Grewal, I. (2014). Racial sovereignty and 'shooter' violence, Sikh Formations, 9(2), 187197.

Huntington, Samuel. (1996). The Clash of Civilizations and the Remaking of World Order. New York, NY: Simon \& Schuster.

Hong, Sukjong. (2013). Half of Asian-American NYC Teens Bullied in School, New Report Finds. Racialicious-the intersection of race and pop culture. Retrieved from http://www.racialicious.com/2013/09/18/half-of-asian-american-nyc-teens-bullied-inschool-new-report-finds/

Iyer, D. (2015). We Too Sing America. New York: The New Press.

Lee, Esther Yu-Hsi (Producer). (2015, January 8, 2016). Sikh Family Takes On Racist Bullying After Teen Was Beaten And Sent To The Hospital. Retrieved from http://thinkprogress.org/immigration/2015/10/16/3712930/sikh-student-whiaapi-anti-bullyingcampaign/

Luxenberg, H., Limber, S.P., \& Olweus, D. (2014). Bullying in U.S. Schools: 2013 Status Report. Center City, MN: Hazelden Foundation.

Maira, S. (2004). Youth culture, citizenship and globalization: South Asian Muslim youth in the United States after September 11th. Comparative Studies of South Asia, Africa and the Middle East, 24(1), 219-231. 
Maira, S. (2009). Missing: Youth, citizenship, and empire after 9/11. Durham: Duke University Press.

Olweus, D. (1993). Bullying at school: What we know and what we can do. New York: WileyBlackwell.

Ong, A. (1996). Cultural citizenship as subject-making: immigrants negotiate racial and cultural boundaries in the United States. Current Anthropology, 37(5), 737-762.

Paracha, Khoshnoor. (2008). Teen Ambassadors. STOMP Out Bullying. Retrieved from http://www.stompoutbullying.org/index.php/about/teen-ambassadors/

Prashad, Vijay. (2005). How the Hindus Became Jews: American Racism after 9/11. South Atlantic Quarterly Summer 2005 104(3): 583-606; doi:10.1215/00382876-104-3-583

Rana, Junaid. (2011). Terrifying Muslims: Race and labor in the South Asian diaspora. Durham and London: Duke University Press.

Rivera, C. (2014). The Brown Threat: Post-9/11 conflations of Latina/os and Middle Eastern Muslims in the U.S. American imagination. Latino Studies 12, 44-64.

Seattle Civil Rights and Labor History Project, University of Washington (Producer). (n.d., January 10, 2016). 1907 Bellingham Riots Retrieved from https://depts.washington.edu/civilr/bham_intro.htm

SAALT. (2014). Under Suspicion, Under Attack Xenophobic Political Rhetoric and Hate Violence against South Asian, Muslim, Sikh, Hindu, Middle Eastern, and Arab Communities in the U.S. Washington, DC: South Asian Americans Leading Together, retrieved from http://saalt.org/wp-content/uploads/2014/09/SAALT_report_full_links.pdf 
SAALT (2012). A Demographic Snapshot of South Asian Americans. Retrieved from http://saalt.org/wp-content/uploads/2012/09/Demographic-Snapshot-Asian-AmericanFoundation-2012.pdf

Sacirbey, O. (2013). Bullying of Asian-Americans spikes in New York City schools. The Washington Post. Retrieved from http://www.washingtonpost.com/pb/national/religion/bullying-of-asian-americans-spikesin-new-york-city-schools/2013/09/05/cc5e2576-166b-11e3-961cf22d3aaf19ab_story.html

Said, E. (1993). Culture and imperialism. New York, NY: Vintage Books.

Shah, Nirvi. (2011). Combating Anti-Muslim Bias. Teaching Tolerance: A project of the southern poverty law center. Retrieved from http://www.tolerance.org/magazine/number39-spring-2011/feature/combating-anti-muslim-bias.

Sharp, S. \& Smith, P. (2002). School bullying: Insights and perspectives. New York: Routledge.

Sirin, R. \& M. Fine. (2008) Muslim American youth: Understanding hyphenated identities through multiple methods. New York \& London: New York University Press.

Sikh Coalition, Coalition for Asian American Families, Asian American Legal Defense an Education Fund. (2009). Bias-based Harassment in New York City Public Schools: A Report Card on the Department of Education's Implementation of Chancellor's Regulation A-832. AALDEF. Retrieved from http://www.aaldef.org/Bias-basedHarassment-in-NYC-Public-Schools.pdf 
South Asian Youth Action, SAYA. (2013). New York City South Asian youth: critical mass, urgent needs. Retrieved from http://www.saya.org/images/stories/saya_report2013_draft20130916b.pdf

Stein, N. (2007) Bullying, Harassment and Violence among Students. Radical Teacher.

Subramanian, M. (2014). Bullying: The ultimate teen guide. Maryland: Rowman and

Littlefield.

Taylor, E., Gillborn, D., \& Ladson-Billings, G. (2009). Foundations of critical race theory in education. New York City: Routledge Press.

Wang, J., Iannotti, R., Nansel, T. (2009). School Bullying Among US Adolescents: Physical, Verbal, Relational and Cyber. Journal of Adolescent Health 45(4), 368-375.

Weheliye, A. G. (2014). Habeas Viscus: Racializing assemblages, biopolitics, and black feminist theories of the human. Duke University Press.

Yosso, Tara, Villalpando, Octavio, Bernal, Dolores Delgado, \& Solórzano, Daniel G. (2001). Critical Race Theory in Chicana/o Education. Paper presented at the National Association for Chicana and Chicano Studies, Tucson, Arizona.

Young, Robin (Producer). (2016, January 10, 2016). Sikhs, Targeted after San Bernardino, Express Solidarity with Muslims. Retrieved from http://hereandnow.wbur.org/2016/01/07/sikhs-expresssolidarity 